\title{
SCIDiC
}

\author{
International Journal of Dentistry and Oral Science (IJDOS) \\ ISSN: 2377-8075
}

\section{Morphometric Analysis Of The Ramus Of The Mandible For Sex Determination}

Review Article

Santhosh kumar ${ }^{*}$, Keerthana Baskar ${ }^{2}$, Thenmozhi ${ }^{3}$

${ }^{1}$ Reader, Department of Oral and Maxillofacial Surgery, Saveetha Dental College and Hospital, Saveetha University.

${ }^{2}$ Department of Oral and Maxillofacial Surgery, Saveetha Dental College and Hospital, Saveetha University.

${ }^{3}$ Professor and Head of the Department, Department of Anatomy, Saveetha Dental College and Hospital, Saveetha University.

\begin{abstract}
Skeletal identification is the initial step in forensics and plays a major role in the identification process. Skull bone is known to show the second most sexual dimorphism, following pelvis with an accuracy rate of $92 \%$. It is relatively hard to find an intact skull. Mandible plays an important role in sex determination as it is the strongest and largest bone showing sexual dimorphism in the skull. This study was aimed to assess the accuracy of morphometric analysis of ramus of mandible in predicting the sex of an individual. This study was done on 30 mandibles in Saveetha Dental college. Careful assessment was made from the measurements of the ramus of the mandible and results obtained. It was observed that the antero-posterior length of the ramus in right side in males and females was $4.625 \mathrm{~cm}$ and $4.198 \mathrm{~cm}$ respectively with a mean total of $4.411 \mathrm{~cm}$. The superoinferior height of the ramus in right side in males and females was $5.276 \mathrm{~cm}$ and $4.935 \mathrm{~cm}$ respectively, with a mean total value of $5.105 \mathrm{~cm}$. It can be concluded from our study that the ramus of mandible has satisfactory potential for determination of sex. It can be used for forensic cases such as in mass disaster where only damaged and partially preserved mandibles are frequently found.
\end{abstract}

Keywords: Mandible; Ramus; Forensic; Skull; Bone; Identification; Morphometric; Sex.

\section{Introduction}

Skeletal identification is the initial step in forensics and plays a major role in the identification process. Skull bone is known to show the second most sexual dimorphism, following pelvis with an accuracy rate of $92 \%$. Males have a larger and stronger bone when compares to that of the females. Morphometric analysis of the ramus of the mandible tends to show greater dimorphism than the body of the mandible. Hence this can be used as a method of sex determination [1].

Sex determination of the deceased is easy to identify if all the skeletal remains are present. The accuracy of sex determination also is $100 \%$. But more often than not, only fragments of bones are available in case of a mass disaster or a natural calamity. This hardens the process of sex determination and the accuracy also decreases to a large extent [2]. It is relatively hard to find an intact skull. In such circumstances, mandible plays an important role in sex determination. It is the strongest and largest bone showing sexual dimorphism in the skull $[3,4]$. The mandible is a durable bone due to the thick layer of cortical bone. The sexual dimorphism in mandible is because of the size and shape of the bone. The muscles of mastication also influence the dimorphism of the bone [5].

Males exert greater force of mastication when compared to that of the females [6]. From the previous studies, it is evident that the mandibular condyle and the ramus show greater dimorphism in

\section{*Corresponding Author:}

Santhosh kumar,

Reader, Department of Oral and Maxillofacial Surgery, Saveetha Dental College and Hospital, Saveetha Institute of Medical and Technical Sciences (SIMATS) Saveetha University 162, Poonamallee High Road, Velappanchavadi, Chennai 600077 Tamil Nadu, India. Tel: +919994892022

Email Id: santhoshsurgeon@gmail.com

Received: February 02, 2021

Accepted: February 28, 2021

Published: March 02, 2021

Citation: Santhosh kumar, Keerthana Baskar, Thenmozhi. Morphometric Analysis Of The Ramus Of The Mandible For Sex Determination. Int J Dentistry Oral Sci. 2021;08(03):18211824. doi: http://dx.doi.org/10.19070/2377-8075-21000361

Copyright: Santhosh kumar $^{\circ} 2021$. This is an open-access article distributed under the terms of the Creative Commons Attribution License, which permits unrestricted use, distribution and reproduction in any medium, provided the original author and source are credited. 
the mandible. These sites are associated with the greatest change in the size and the remodelling during growth. The measurements of the mandibular ramus presentthe greater variation among the males and females when compared to the body of the mandible [7]. Morphometric analysis is accurate and they can be used to identify the sex of the individual [8].

Radiographs have become important in the investigation and diagnosis process. Dentofacial radiographs are taken routinely in the dental and medical offices for diagnostic purposes [9]. A rotational panoramic radiograph provides a comprehensive view of the oral and maxillofacial complex. In forensics, the antemortem and post-mortem radiographs are compared to help in the positive identification of the human remains [10]. This study was aimed to assess the accuracy of morphometric analysis of ramus of mandible in predicting the sex of an individual.

\section{Materials and Methods}

Mandibular skeletons present in Saveetha Dental College were used for this study. 30 Ideal skeletal bones without any deformities were chosen for the study. The study was conducted by carefully analysing the angle and the ramus of the mandible. A vernier calliper was used to determine the various parameters for the study. The parameters that were chosen for the study included:
Supero-inferior height of the ramus of the mandible (Figure 1) and Antero-posterior length of the ramus of the mandible (Figure 2) on both the sides of the mandible. The divider points were held against the points of measurement. Then divider was placed against the Digital Vernier calliper and the readings were noted down. Three measurements of each parameter were taken so that an average could be taken and the observer error value could be significantly reduced. The measurements were recorded by an individual and all the values were rounded to two decimal places.

\section{Results}

The antero-posterior length of the ramus in right side in males and females was $4.625 \mathrm{~cm}$ and $4.198 \mathrm{~cm}$ respectively with a mean total of $4.411 \mathrm{~cm}$ [Table 1]. The antero-posterior length of the ramus in left side in males and females was $4.328 \mathrm{~cm}$ and $4.255 \mathrm{~cm}$ respectively with a mean total of $4.292 \mathrm{~cm}$ [Table 1].

The supero-inferior height of the ramus in right side in males and females was $5.276 \mathrm{~cm}$ and $4.935 \mathrm{~cm}$ respectively with a mean total of $5.105 \mathrm{~cm}$ [Table 2]. The supero-inferior height of the ramus in left side in males and females was $5.091 \mathrm{~cm}$ and 4.672 $\mathrm{cm}$ respectively with a mean total of $4.882 \mathrm{~cm}$ [Table 2]. Overall, the measurements in males were higher than that of the females. It was found that 14 male mandibles and 16 female mandibles

Figure 1. Measurement of Supero-inferior height of the ramus of the mandible.

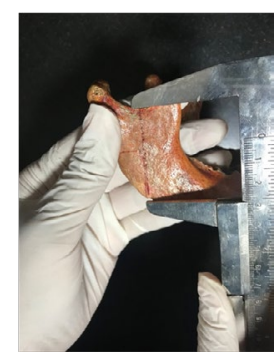

Figure 2 Measurement of antero-posterior length of the ramus of the mandible.

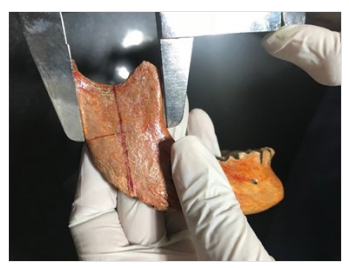

Table 1. Measurements of Antero-posterior length of the ramus of the mandible.

\begin{tabular}{|c|c|c|}
\hline Sex & $\begin{array}{c}\text { Right side } \\
\text { length }(\mathbf{c m})\end{array}$ & $\begin{array}{c}\text { Left side } \\
\text { length } \mathbf{( c m})\end{array}$ \\
\hline Male & 4.625 & 4.328 \\
\hline Female & 4.198 & 4.255 \\
\hline
\end{tabular}

Table 2. Measurements of Supero-inferior height of the ramus of the mandible.

\begin{tabular}{|c|c|c|}
\hline Sex & $\begin{array}{c}\text { Right side height } \\
(\mathbf{c m})\end{array}$ & $\begin{array}{c}\text { Left side height } \\
\text { (cm) }\end{array}$ \\
\hline Male & 5.276 & 5.091 \\
\hline Female & 4.935 & 4.672 \\
\hline
\end{tabular}


could be identified.

\section{Discussion}

Sex determination morphometrically has been an older approach in the forensic and medico-legal examination. The method used for determination may be different depending upon the conditions such as availability of the bones and their conditions. Determination of sex through bony remains is significant during mass disasters and fatalities where only the bones of the deceased remain for investigation as they are damaged beyond recognition. When the entire skeleton is present, the accuracy rate of sex determination is $100 \%$ as it can be determined by the pelvic bone. However, in majority of the accidents only a fragment of the bone is available for investigation. Skull is the hardest and one of the bones that usually remains after a disaster and thus can be used in forensics. Mandible is one of the bones that exhibits sexual dimorphism and hence it can be used to determine the sex of the individual [11].

When the forensic data are unavailable, anthropometric analysis of the intraoral regions can be useful [8]. A study conducted by Kambylafkas et al showed that the evaluation of the total height of the ramus is reliable [12]. The best parameter used in a study for identification of the sex was the height of the ramus of the mandible [2]. Saini et al found that coronoid height proved to be the best to determine the sex of an individual with an accuracy rate of $74.1 \%$ and combining with minimum ramus height, minimum ramus breadth and / or ramus length had an accuracy rate of $80.2 \%$ [13]. Another study conducted by Indira et al, on mandibular measurements using orthopantomograph was found statistically significant using the discrimination functional analysis. There was significant sex determination suggesting that mandible is a strongly dimorphic bone [14].

Shiva prakash et al conducted a study in sex determination by analysing the mandibular ramus posterior flexure. The study had an accuracy rate of $80 \%$, where sex was determined in 44 cases out of 55 male mandibles with an accuracy rate of $80 \%$, and sex was accurately determined in 35 cases out of 49 female mandibles with accuracy rate of $71 \%$ [15]. Significant difference was present between the different variables which includes: bicondylar breadth, bigonial angle and minimum ramus breadth according to the study done by Kharoshah et al [16]. Loth et al determined the sex using a single variable which was the presence or absence of flexure of the posterior border of the ramus with an accuracy of $90.6 \%-99 \%$ [17]. There was no significant difference observed in mandibular angle in sex determination in the young Lebanese population (83 young individuals consisting of 40 males and 43 females) aged between 17 and 26 years in a study that was conducted by Ayoub et al [18].

Study done by Steyn et al showed bigonial breadth was the most dimorphic of the parameters that were considered [19]. Study conducted by Samatha et al also concluded that sex was accurately determined in 32 cases out of sixty male mandibular measurements with prediction accuracy rate of $53 \%$ and sex was accurately determined in 36 cases out of sixty female mandibular measurements with accuracy rate of $60 \%$ [1]. The socio-environmental factors (e.g. nutrition, food, climate, pathologies, etc.) influence the development, and thus the appearance of bones. Also, sex determination is difficult in edentulous patients and people in the sub-adult age [20]. With a rich case bank established over the last decades we have been able to publish extensively in our domain [21-24]. Further large-scale trials are required to establish the precision of morphometric analysis of the ramus of the mandible for sex determinationin our study population.

\section{Conclusion}

It can be concluded from our study that the ramus of mandible has satisfactory potential for determination of sex. It can be used for forensic cases such as in mass disaster where only damaged and partially preserved mandibles are frequently found. The ramus of the mandible and the condyle were found to be the most dimorphism part of the mandibular bone, and to a lesser extent the lateral body. The variation could be dueto differential growth trajectories and functional adaptations.

\section{References}

[1]. Samatha K, Byahatti SM, Ammanagi RA, Tantradi P, Sarang CK, Shivpuje P. Sex determination by mandibular ramus: A digital orthopantomographic study. J Forensic Dent Sci. 2016 May-Aug;8(2):95-8. PubmedPMID: 27555726.

[2]. Oettlé AC, Pretorius E, Steyn M. Geometric morphometric analysis of mandibular ramus flexure. American Journal of Physical Anthropology: The Official Publication of the American Association of Physical Anthropologists. 2005 Nov;128(3):623-9.

[3]. Scheuer L. Application of osteology to forensic medicine. Clin Anat. 2002 Jun;15(4):297-312. PubmedPMID: 12112359.

[4]. Durić M, Rakocević Z, Donić D. The reliability of sex determination of skeletons from forensic context in the Balkans. Forensic Sci Int. 2005 Jan 29;147(2-3):159-64. PubmedPMID: 15567621.

[5]. Hu KS, Koh KS, Han SH, Shin KJ, Kim HJ. Sex determination using nonmetric characteristics of the mandible in Koreans. J Forensic Sci. 2006 Nov;51(6):1376-82. PubmedPMID: 17199624.

[6]. Franklin D, O'Higgins P, Oxnard CE, Dadour I. Discriminant function sexing of the mandible of indigenous South Africans. Forensic Sci Int. 2008 Jul 18;179(1):84.e1-5. PubmedPMID: 18467049.

[7]. Humphrey LT, Dean MC, Stringer CB. Morphological variation in great ape and modern human mandibles. J Anat. 1999 Nov; 195 ( Pt 4)(Pt 4):491513. PubmedPMID: 10634689.

[8]. Vodanović M, Dumančić J, Demo Ž, Mihelić D. Determination of sex by discriminant function analysis of mandibles from two Croatian archaeological sites. Acta Stomatologica Croatica. 2006 Sep 1;40(3):263-77.

[9]. Sassouni V. Dentofacial radiography in forensic dentistry. Journal of Dental Research. 1963 Jan;42(1):274-302.

[10]. Schulze R, Krummenauer F, Schalldach F, d'Hoedt B. Precision and accuracy of measurements in digital panoramic radiography. Dentomaxillofac Radiol. 2000 Jan;29(1):52-6. PubmedPMID: 10654037.

[11]. Raj JD, Ramesh S. Sexual dimorphism in mandibular ramus of South Indian population. Antrocom Online J Anthropol. 2013 Jan 1;9:253-8.

[12]. Kambylafkas P, Murdock E, Gilda E, Tallents RH, Kyrkanides S. Validity of panoramic radiographs for measuring mandibular asymmetry. Angle Orthod. 2006 May;76(3):388-93. PubmedPMID: 16637716.

[13]. Saini V, Srivastava R, Rai RK, Shamal SN, Singh TB, Tripathi SK. Mandibular ramus: an indicator for sex in fragmentary mandible. J Forensic Sci. 2011 Jan;56 Suppl 1:S13-6. PubmedPMID: 20950321.

[14]. Indira AP, Markande A, David MP. Mandibular ramus: An indicator for sex determination - A digital radiographic study. J Forensic Dent Sci. 2012 Jul;4(2):58-62. PubmedPMID: 23741142.

[15]. Shivaprakash S, Vijaykumar AG. Sex determination by using mandibular ramus posterior flexure-A prospective study. Int J Health Sci Res. 2014;4(1):155-9.

[16]. Kharoshah MA, Almadani O, Ghaleb SS, Zaki MK, Fattah YA. Sexual dimorphism of the mandible in a modern Egyptian population. J Forensic Leg Med. 2010 May;17(4):213-5. PubmedPMID: 20382358.

[17]. Loth SR, Henneberg M. Sexually dimorphic mandibular morphology in the first few years of life. Am J Phys Anthropol. 2001 Jun;115(2):179-86. PubmedPMID: 11385604.

[18]. Ayoub F, Rizk A, Yehya M, Cassia A, Chartouni S, Atiyeh F, Majzoub Z. 
Sexual dimorphism of mandibular angle in a Lebanese sample. J Forensic Leg Med. 2009 Apr;16(3):121-4. PubmedPMID: 19239960.

[19]. Steyn M, Işcan MY. Sexual dimorphism in the crania and mandibles of South African whites. Forensic Sci Int. 1998 Nov 30;98(1-2):9-16. PubmedPMID: 10036755.

[20]. Suazo Galdames IC, Zavando Matamala DA, Smith RL. Evaluating Accuracy and Precision in Morphologic Traits for Sexual Dimorphism in Malnutrition Human Skull: a Comparative Study. International Journal of Morphology. 2008 Dec 1;26(4).

[21]. Kumar MS. Knowledge, attitude and practices towards oral health among law students in Chennai. Journal of Pharmaceutical Sciences and Research. 2016 Jul 1;8(7):650.

[22]. Kumar MP. Dental management of patients on antiplatelet therapy: Literature update. Asian J Pharm Clin Res. 2016;9(3):26-31.

[23]. Kumar S. Newer delivery systems for local anesthesia in dentistry. J Pharm Sci Res. 2015;7(5):252-5.

[24]. Malay KK, Duraisamy R, Brundha MP, Kumar MP. Awareness regarding anemia among 1 st year dental undergraduate students. Drug Invention Today. 2018 Aug $1 ; 10(8)$. 